\title{
Comparison of Postreceptor Effects of 1-34 Human Hypercalcemia Factor and 1-34 Human Parathyroid Hormone in Rat Osteosarcoma Cells
}

\author{
Sevgi B. Rodan, Masaki Noda, Gregg Wesolowski, Michael Rosenblatt, and Gideon A. Rodan \\ Departments of Bone Biology and Osteoporosis Research, and Biological Research and Molecular Biology, Merck Sharp \& Dohme \\ Research Laboratories, West Point, Pennsylvania 19486
}

\begin{abstract}
A tumor-derived factor believed to cause hypercalcemia by acting on the parathyroid hormone (PTH) receptor was recently purified, cloned, and found to have $\mathrm{NH}_{2}$-terminal sequence homology with PTH. The 1-34 region of this protein was synthesized, evaluated for its postreceptor effects on the ROS 17/2.8 cell line, and its properties were compared to 1-34 PTH. Both 1-34 human humoral hypercalcemia factor (HCF) and 1-34 PTH stimulated adenylate cyclase with an effective concentration (EC) so $_{\mathbf{~}}$ of $\sim 1 \mathrm{nM}$. The extent of stimulation by both peptides was equally enhanced by dexamethasone. They both had a pronounced inhibitory effect on growth in the presence of dexamethasone, with an $\mathrm{EC}_{s_{0}}$ of $\sim 0.1 \mathrm{nM}$, reduced alkaline phosphatase (AP) activity by $\sim 70 \%$ in the absence of dexamethasone and by $\sim 80 \%$ in the presence of dexamethasone with an $\mathrm{EC}_{\mathbf{s}}$ of $0.03 \mathrm{nM}$, and when present at a concentration of $10 \mathrm{nM}$, reduced AP mRNA levels (estimated by Northern analysis) by $\sim 80 \%$ in the presence or absence of dexamethasone. Thus, in addition to similar dose-response curves for adenylate cyclase stimulation, both HCF and PTH produced identical postreceptor effects in ROS 17/2.8 cells. These effects of HCF are probably mediated by the interaction of the tumor-derived factor with the PTH receptor.
\end{abstract}

\section{Introduction}

Hypercalcemia is a frequent complication of malignancy; the clinical syndrome resembles hyperparathyroidism in several aspects. Recently, a factor secreted by the tumors of patients suffering from hypercalcemia was found to possess $\mathrm{NH}_{2}$-terminal sequence homology to PTH (1-3). The tumor-derived factors stimulate kidney and bone adenylate cyclase. Presumably, these effects occur via interaction with the PTH receptor, since

Address all correspondence to Dr. Gideon A. Rodan, Executive Director, Department of Bone Biology and Osteoporosis Research, Merck Sharp \& Dohme Research Laboratories, West Point, PA 19486.

Received for publication 26 October 1987 and in revised form 14 December 1987.

1. Abbreviations used in this paper: AP, alkaline phosphatase; EC, effective concentration; FBS, fetal bovine serum; HCF, human humoral hypercalcemia factor.

J. Clin. Invest.

(c) The American Society for Clinical Investigation, Inc.

0021-9738/88/03/0924/04 \$2.00

Volume 81, March 1988, 924-927 they are inhibited by the PTH antagonist $\left[{ }^{8}\right.$ norleucyl, ${ }^{18}$ norleucyl, ${ }^{34}$ tyrosinyl]PTH $(3-34)$ amide $(4,5)$. It is therefore assumed that the clinically relevant hypercalcemia is also produced by human humoral hypercalcemia factor's (HCF) interaction with the PTH receptor. The recent elucidation of the sequence of the HCF $(1,6)$ made it possible to synthesize a fragment of the factor and examine directly its effects on PTH-responsive cells.

ROS 17/2.8 and other cells of the osteoblastic lineage possess adenylate cyclase-coupled PTH receptors which may be involved in the bone resorptive action of PTH (7). It has also been suggested that not all PTH effects are produced by adenylate cyclase stimulation, and that receptor-mediated changes in intracellular calcium (8) may be involved in bone resorption (9). Although it has been demonstrated that the tumor-derived factors stimulate adenylate cyclase in osteoblastic cells, it has not been shown that they produce biological effects similar to those of PTH. In view of these possibilities, we examined the nature and relative efficacy of PTH (1-34) and HCF (1-34) in promoting several different postreceptor effects in the osteoblastic osteosarcoma cell line ROS 17/2.8.

\section{Methods}

Materials. Culture plasticware was purchased from Costar, Data Packaging Corp. (Cambridge, MA) or Nunc/InterLab (Thousand Oaks, CA). Culture medium and kanamycin were obtained from Grand Island Biological Co. (Grand Island, NY) and fetal bovine serum (FBS) was from Hazelton Systems, Inc. (Lenexa, KS). Human PTH (1-34) was from Bachem Biochemical (Torrance, CA). Vanadyl ribonucleoside complexes and agarose were purchased from Bethesda Research Laboratories (Bethesda, MD). Oligo-labeling kits were from Pharmacia Fine Chemicals (Piscataway, NJ). Proteinase K was purchased from International Biotechnologies, Inc. (New Haven, CT). $\left[{ }^{3} \mathrm{H}\right.$ ]Adenine was supplied by New England Nuclear (Boston, MA). Other reagents were purchased from Sigma Chemical Co. (St. Louis, MO).

Adenylate cyclase assay. cAMP was measured using cells labeled with $\left[{ }^{3} \mathrm{H}\right]$ adenine as described previously (5).

Northern analysis. For Northern analysis cells were plated into 500 $\mathrm{cm}^{2}$ dishes and RNA was prepared as described by Greenberg and Ziff (11). RNA was fractionated on $0.8 \%$ formaldehyde agarose gel and transferred to nylon filters (Hybond N; Amersham Corp., Arlington Heights, IL) by electroblotting (12). Filters were subsequently hybridized to ${ }^{32} \mathrm{P}$-labeled CDNA AP probe as described before (13). mRNA levels were estimated by scanning densitometry using a densitometer (Hoefer Scientific Instruments, San Francisco, CA).

$A P$ assay. AP activity was measured as described previously (10). Briefly, cell media were removed, cells were washed two times with calcium-magnesium free $\mathrm{HBSS}$, and disrupted with $10 \mathrm{mM}$ Tris $\mathrm{HCl}$, 
$0.5 \mathrm{mM} \mathrm{MgCl} 2$, and $0.1 \%$ Triton X-100 (pH 7.4). AP activity was measured in the sonicated homogenate. Homogenate protein was measured by the method of Spector (14) using BSA as the standard.

Peptide synthesis. The peptide $\mathrm{HCF}-(1-34) \mathrm{NH}_{2}$ was synthesized with the help of HCF modifications of the Merrifield solid-phase technique (15) using a synthesizer (430A; Applied Biosystems, Inc., Foster City, CA). The peptide was then purified by gel filtration followed by preparative HPLC. The peptide, after chemical analysis, was found to be authentic and of high purity ( $>99 \%$ ) by HPLC, amino acid analysis, Edman sequence analysis, fast atom bombardment mass spectrometry, and proton nuclear magnetic resonance (16).

\section{Results}

Fig. 1 shows dose-dependent stimulation of cAMP accumulation by HCF and PTH in cells grown in the presence of dexamethasone and the respective controls. The effective concentration $(E C)_{50}$ for adenylate cyclase stimulation was the same $(\sim 1 \mathrm{nM})$ for either peptide with or without dexamethasone treatment. However, in the absence of dexamethasone, HCF was slightly more stimulatory compared with PTH. In the presence of dexamethasone, this difference disappeared and the dose-response curves of the two peptides overlapped (Fig. $1 B)$.

Fig. 2 depicts the growth curve of $17 / 2.8$ cells treated with dexamethasone in the presence and absence of HCF and PTH. As previously shown (10), dexamethasone (30 nM) inhibited the growth of ROS $17 / 2.8$ cells by $\sim 45 \%$. In the presence of dexamethasone, HCF and PTH (10 nM) inhibited growth by an additional $60 \%$.

The growth inhibitory effects of HCF and PTH were dose dependent (Fig. 3). In the absence of dexamethasone, neither peptide inhibited growth of ROS 17/2.8 cells. In the presence of dexamethasone both peptides inhibited growth with an $\mathrm{EC}_{50}$ of $\sim 0.1 \mathrm{nM}$.

We next compared the effects of HCF and PTH on AP activity (Fig. 4). Both HCF and PTH inhibited AP activity in a dose-dependent manner by $70 \%$ in the absence of dexametha-

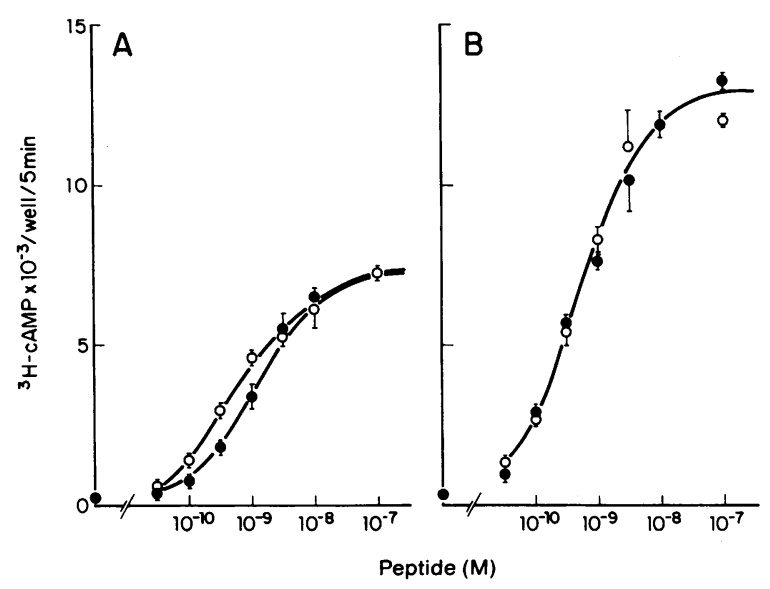

Figure 1. The effect of dexamethasone on PTH and HCF stimulation of adenylate cyclase in ROS $17 / 2.8$ cells. ROS $17 / 2.8$ cells were plated at $20,000 / \mathrm{cm}^{2}$ in F-12 medium containing 5\% FBS. $3 \mathrm{~d}$ after plating dexamethasone $(30 \mathrm{nM})(B)$ or vehicle $(0.0025 \%$ ethanol) $(A)$ was added for $4 \mathrm{~d}$. Adenylate cyclase was estimated in whole cells as described in Methods. Cells were incubated for $5 \mathrm{~min}$ with the indicated concentrations of PTH (๑) or HCF (o) in the presence of 1 $\mathrm{mM}$ isobutylmethylxanthine. Values are the mean $\pm \mathrm{SD}$ of triplicate wells from one of four similar experiments.

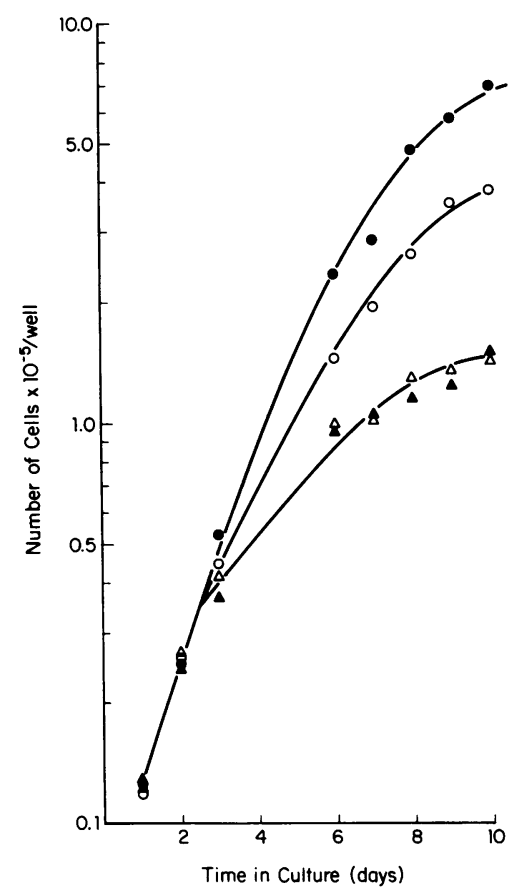

Figure 2. Growth curve of $\operatorname{ROS} 17 / 2.8$ cells treated with dexamethasone, HCF, and PTH. ROS $17 / 2.8$ cells were plated in 24 multi-well dishes at $5000 / \mathrm{cm}^{2}$ in 1 $\mathrm{ml}$ F-12 medium containing 5\% FBS. $1 \mathrm{~d}$ after plating, dexamethasone (0) $(30 \mathrm{nM})$, ethanol $(0.0025 \%)(\bullet)$, dexamethasone + PTH $(10 \mathrm{nM})(\Delta)$, and dexamethasone + HCF (10 $\mathrm{nM})(\Delta)$ were added to each well. Cultures were fed on d 1, 2, 3, 4, and 6 . Cells were trypsinized, and cell number was determined using a counter (Coulter Electronics, Inc., Hialeah, FL) at the indicated times. Data are the mean values of three wells from one of two similar experiments.

sone and by $83 \%$ in dexamethasone-treated cells with the same $\mathrm{EC}_{50}$ of $0.03 \mathrm{nM}$.

Northern analysis showed that HCF and PTH (both at 10 $\mathrm{nM}$ ) inhibited AP mRNA ( $2.5 \mathrm{~kb}$ band) by about $80 \%$ after $3 \mathrm{~d}$ of treatment (Fig. 5). Dexamethasone increased AP mRNA four- to fivefold. PTH and HCF reduced the dexamethasoneenhanced mRNA levels by $80 \%$.

\section{Discussion}

Our studies demonstrate that all the biological effects produced in this investigation by 1-34 human PTH in the PTH-

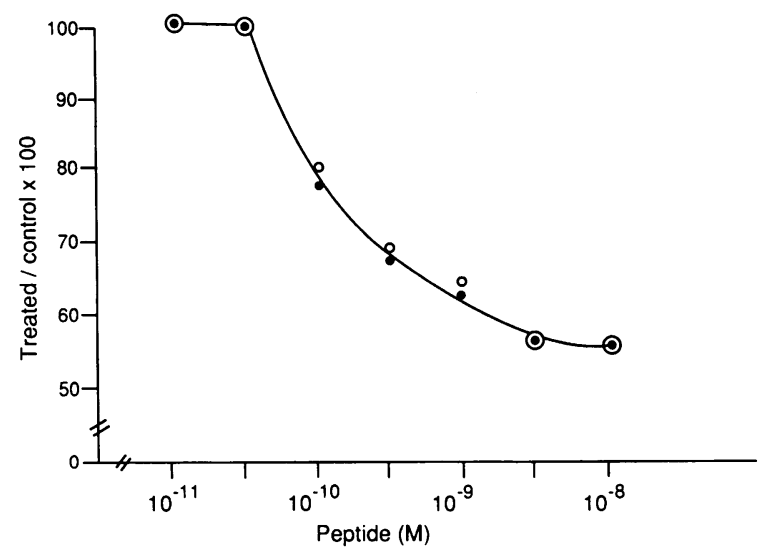

Figure 3. Dose-dependent inhibition of growth by HCF and PTH in the presence of dexamethasone. ROS $17 / 2.8$ cells were plated at $5000 / \mathrm{cm}^{2}$ in 24 multi-well dishes in $1 \mathrm{ml}$ medium containing $5 \%$ FBS. $3 \mathrm{~d}$ after plating, dexamethasone $(30 \mathrm{nM})$ was added with or without PTH (•) or HCF (o). Cultures were refed on day 3 and counted on day 6. Data are the mean values of three culture wells from one of two similar experiments. 


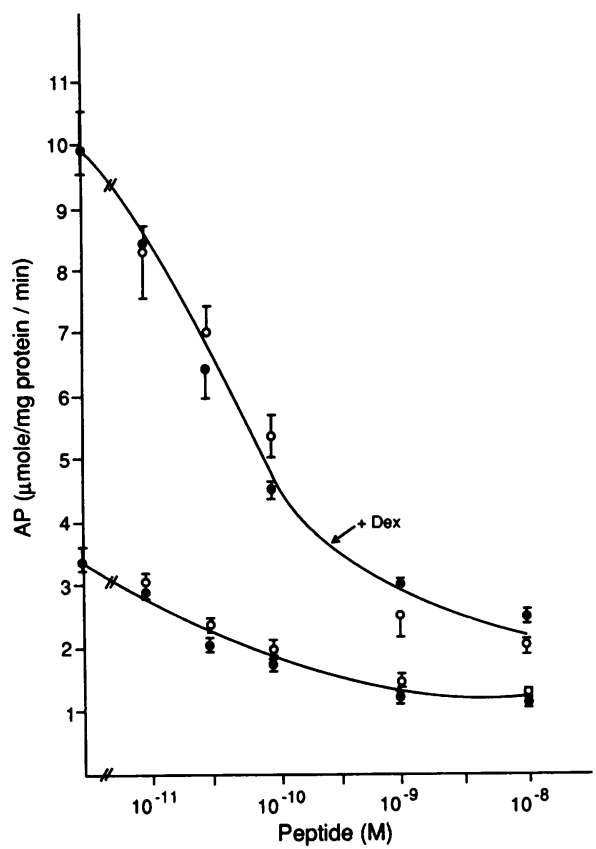

Figure 4. Dose-dependent inhibition of AP by HCF and PTH in the presence and absence of dexamethasone. ROS 17/2.8 cells were plated at $20,000 / \mathrm{cm}^{2}$ in F-12 medium with $5 \%$ FBS in 24-well multidishes. $4 \mathrm{~d}$ later dexamethasone $(30 \mathrm{nM})$ or ethanol $(0.0025 \%)$ were added either with HCF (o) or PTH (๑) at the indicated concentrations. AP activity and protein concentration were determined after 3 $\mathrm{d}$ of treatment. Data are the mean \pm SD of determinations from triplicate wells from one of two similar experiments.

sensitive rat osteosarcoma ROS $17 / 2.8$ cells were also produced by 1-34 HCF. Moreover, the dose-response curves generated for the postreceptor effects were virtually overlapping in all instances for both synthetic peptides used in this study.

The HCF preparation was slightly more potent in stimulating adenylate cyclase, as previously observed by Moseley et al. (1) in UMR 106 cells. However, dexamethasone treatment,

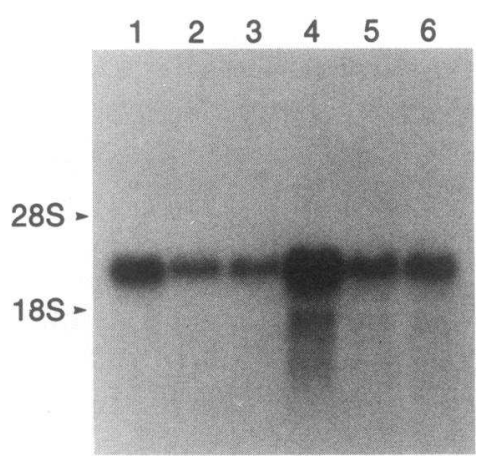

Figure 5. Northern blot analysis of mRNA for AP. ROS $17 / 2.8$ cells were plated at $20,000 / \mathrm{cm}^{2}$ in $500 \mathrm{~cm}^{2}$ dishes. $3 \mathrm{~d}$ later, cells were treated for an additional $3 \mathrm{~d}$ as described below. Total RNA was extracted, and equivalent amounts of RNA $(10 \mu \mathrm{g})$ were electrophoresed in agarose/formaldehyde gels, blotted to nylon filters and hybridized with the cDNA probe for rat AP. Lane 1, F-12 medium containing 5\% FBS and ethanol $(0.0025 \%)+0.001 \%$ acetic acid, $0.001 \%$ BSA; lane 2, $10 \mathrm{nM}$ HCF; lane 3, $10 \mathrm{nM}$ PTH; lane 4, $30 \mathrm{nM}$ dexamethasone; lane 5, dexamethasone + HCF; lane 6, dexamethasone + PTH. The AP activities were measured for each lane and were $1.8,0.8,0.9,8.5,1.3$, and $2 \mu \mathrm{mol} / \mathrm{min}$ per $\mathrm{mg}$ protein, respectively. This is one of two similar experiments. which was shown to increase the level of $\mathrm{G}_{\mathbf{3}}$ (cholera toxinstimulated NAD-ribosylation of G protein) in ROS 17/2.8 cells (17), equalized the dose-response curves for the two peptides. All biological effects were seen at lower concentrations than those required for adenylate cyclase stimulation. For example, the $\mathrm{EC}_{50}$ for $\mathrm{AP}$ inhibition was $\sim 30 \mathrm{pM}$; for adenylate cyclase stimulation, it was around $1 \mathrm{nM}$. This phenomenon is frequently observed in hormonal systems, and is commonly attributed to "spare" receptors (18), a relatively small amount of CAMP suffices to produce the full biological effect.

HCF and PTH inhibited the growth of ROS 17/2.8 cells only in the presence of dexamethasone. This is of interest since dexamethasone treatment was shown to be needed for PTHstimulation of cAMP-dependent protein kinase in these cells (19) and the activation of protein kinase isoenzyme I is believed to play a role in cell proliferation (20). PTH was shown to stimulate predominantly the isoenzyme I of cAMP-dependent protein kinase (21) and to inhibit growth (22) in the osteogenic sarcoma cell line UMR 106.

AP is a major osteoblastic marker. The level of this enzyme in ROS 17/2.8 cells was shown to increase with dexamethasone treatment and decrease in response to PTH (10). Northern analysis indicated that these changes were accompanied by parallel changes in AP mRNA. HCF produced effects identical to PTH on AP activity and AP mRNA. PTH and HCF inhibited AP to the same extent $(\sim 70-80 \%)$ and with the same $\mathrm{EC}_{50}$ in the presence and absence of dexamethasone. This is consistent with previous findings showing that glucocorticoid potentiation of adenylate cyclase stimulation and of other PTH effects in calvarial osteoblasts (23) and osteosarcoma cells (24) did not alter hormone affinity.

In conclusion, we have shown that a chemically synthesized fragment of HCF produces a profile of postreceptor effects identical to PTH in ROS 17/2.8 cells. Furthermore, the potency of HCF across the spectrum of effects studied is comparable to PTH. These findings support the hypothesis that HCF produces PTH-like effects on bone and that these effects are mediated via interaction with the PTH receptor.

\section{Acknowledgments}

We would like to thank Dr. Ruth Nutt, Mr. Jay Levy, and Mr. Tom Gay for the preparation and characterization of 1-34 HCF.

\section{References}

1. Moseley, J. M., M. Kubota, H. D. Diefenbach-Jagger, R. E. H. Wettenhall, B. E. Kemp, L. J. Suva, C. P. Rodda, P. R. Ebeling, P. J. Hudson, J. D. Zajac, and T. J. Martin. 1987. Parathyroid hormonerelated protein purified from a human lung cancer cell line. Proc. Natl. Acad. Sci. USA. 84:5048-5052.

2. Stewart, A. F., T. Wu, D. Goumas, W. J. Burtis, and A. E. Broadus. 1987. N-Terminal amino acid sequence of two novel tumorderived adenylate cyclase-stimulating proteins: identification of parathyroid hormone-like and parathyroid hormone unlike domains. Biochem. Biophys. Res. Commun. 146:672-678.

3. Strewler, G. J., P. H. Stern, J. W. Jacobs, J. Eveloff, R. F. Klein, S. C. Leung, M. Rosenblatt, and R. A. Nissenson. 1987. Parathyroid hormone-like protein from human renal carcinoma cells: structural and functional homology with parathyroid hormone. J. Clin. Invest. 80:1803-1807.

4. Stewart, A. F., K. L. Insogna, D. Goltzman, and A. E. Broadus. 1983. Identification of adenylate cyclase-stimulating activity and cyto- 
chemical glucose-6-phosphate dehydrogenase-stimulating activity in extracts of tumors from patients with humoral hypercalcemia of malignancy. Proc. Natl. Acad. Sci. USA. 80:1454-1458.

5. Rodan, S. B., K. L. Insogna, A. M.-C. Vignery, A. F. Stewart, A. E. Broadus, S. M. D'Souza, D. R. Bertolini, G. R. Mundy, and G. A. Rodan. 1983. Factors associated with humoral hypercalcemia of malignancy stimulate adenylate cyclase in osteoblastic cells. J. Clin. Invest. 72:1511-1515.

6. Suva, L. J., G. A. Winslow, R. E. H. Wettenhall, R. G. Hammonds, J. M. Moseley, H. Diefenbach-Jagger, C. P. Rodda, B. E. Kemp, H. Rodriguez, E. Y. Chen, P. J. Hudson, T. J. Martin, and W. I. Wood. 1987. A parathyroid hormone-related protein implicated in malignant hypercalcemia:cloning and expression. Science (Wash. DC). 237:893-896.

7. Rodan, G. A., and T. J. Martin, 1981. Role of osteoblasts in hormonal control of bone resorption-a hypothesis. Calcif. Tissue Int. 33:349-351.

8. Yamaguchi, D. T., T. J. Hahn, A. Iida-Klein, C. R. Kleeman, and S. Muallem. 1987. Parathyroid hormone-activated calcium channels in an osteoblast-like clonal osteosarcoma cell line. J. Biol. Chem. 262:7711-7718.

9. Lowik, C. W. G. M., J. P. T. M. van Leeuwen, J. M. vander Meer, J. K. van Zeeland, B. A. A. Scheven, and M. P. M. HerrmannErlee. 1985. A two receptor model for the action of parathyroid hormone on osteoblasts: a role for intracellular free calcium and cAMP. Cell Calcium. 6:311-326.

10. Majeska, R. J., B. C. Nair, and G. A. Rodan. 1985. Glucocorticoid regulation of alkaline phosphatase in the osteoblastic osteosarcoma cell line ROS 17/2.8. Endocrinology 116:170-179.

11. Greenberg, M. E., and E. B. Ziff. 1984. Stimulation of 3T3 cells induces transcription of the c-fos proto-oncogene. Nature (Lond.). 311:433-438.

12. Thomas, P. 1980. Hybridization of denatured RNA and small DNA fragments transferred to nitrocellulose. Proc. Natl. Acad. Sci. USA. 77:5201-5205.

13. Noda, M., M. Thiede, R. Buenaga, K. Yoon, M. Weiss, $P$. Henthorn, H. Harris, and G. A. Rodan. 1987. cDNA cloning of alkaline phosphatase from rat osteosarcoma (ROS 17/2.8) cells. J. Bone Mineral Res. 2:161-164.
14. Spector, T. 1978. Refinement of the Coomassie blue method of protein quantitation. Anal. Biochem. 86:142-146.

15. Merrifield, R. B. 1969. Solid phase peptide synthesis. $A d v$. Enzymol. Relat. Subj. Biochem. 32:221-296.

16. Horiuchi, N., M. P. Caulfield, J. E. Fisher, M. E. Goldman, R. L. McKee, J. E. Reagan, J. J. Levy, R. F. Nutt, S. B. Rodan, T. L. Schofied, T. L. Clemens, and M. Rosenblatt. 1987. Similarity of synthetic peptide from human tumor to parathyroid hormone in vivo and vitro. Science (Wash. DC). 238:1566-1568.

17. Rodan, S. B., and G. A. Rodan. 1986. Dexamethasone effects on $\beta$-adrenergic receptors and adenylate cyclase regulatory proteins $G_{s}$ and $G_{i}$ in ROS 17/2.8 cells. Endocrinology. 118:2510-2518.

18. Terasaki, W. L., J. Linden, and G. Brooker. 1979. Quantitative relationship between $\beta$-adrenergic receptor number and physiologic responses as studied with a long lasting $\beta$-adrenergic antagonist. Proc. Natl. Acad. Sci. USA. 76:6401-6405.

19. Zajac, J. D., S. A. Livesey, V. P. Michelangeli, S. B. Rodan, G. A. Rodan, and T. J. Martin. 1986. Glucocorticoid treatment facilitates cyclic adenosine 3',5'-monophosphate-dependent protein kinase response in parathyroid hormone-responsive osteogenic sarcoma cells. Endocrinology. 118:2059-2064.

20. Ng, K. W., S. A. Livesey, R. G. Larkins, and T. J. Martin. 1983. Calcitonin effects on growth and on selective activation of type II isoenzyme of cyclic adenosine 3':5"-monophosphate-dependent protein kinase in T47D human breast cancer cells. Cancer Res. 43:794800.

21. Livesey, S. A., B. E. Kemp, C. A. Re, N. C. Partridge, and T. J. Martin. 1982. Selective hormonal activation of cyclic AMP-dependent protein kinase isoenzymes in normal and malignant osteoblasts. J. Biol. Chem. 257:14983-14987.

22. Partridge, N. C., A. L. Opie, R. T. Opie, and T. J. Martin. 1985. Inhibitory effects of parathyroid hormone on growth of osteogenic sarcoma cells. Calcif. Tissue Int. 37:519-525.

23. Chen, T. L., and D. Feldman. 1979. Glucocorticoid receptors and actions in subpopulations of cultured rat bone cells. J. Clin. Invest. 63:750-758.

24. Rodan, S. B., M. K. Fischer, J. J. Egan, P. M. Epstein, and G. A. Rodan. 1984. The effect of dexamethasone on parathyroid hormone stimulation of adenylate cyclase in ROS 17/2.8 cells. Endocrinology. 115:951-958. 